\title{
Selection of prey size and prey species by 1-group cod Gadus morhua: effects of satiation level and prey handling times
}

\author{
Stephen A. Arnott*, Leif Pihl \\ Kristineberg Marine Research Station, 45034 Fiskebäckskil, Sweden
}

\begin{abstract}
We performed laboratory experiments to investigate feeding behaviour of 1-group Atlantic cod Gadus morhua and compared the results with stomach content records from wild 1-group cod feeding within a shallow bay on the west coast of Sweden. On the basis of the field observations, 3 prey species were investigated: juvenile shore crabs Carcinus maenas, brown shrimps Crangon crangon and 0-group plaice Pleuronectes platessa. When fed single species meals in the laboratory, satiation level was mostly independent of prey size, but cod consumed more plaice than shrimps and more shrimps than crabs. Once satiated on crabs, cod ate plaice if they were subsequently offered, but the reverse was not true. The time taken to ingest crabs was independent of the prey:cod (P:C) length ratio, cod length or stomach fullness, whereas plaice and shrimp ingestion times increased with P:C length ratio, and shrimp times also increased with stomach fullness. Consequently, the profitability of crabs increased up until the maximum edible size, whereas shrimp and plaice profitability peaked at P:C length ratios lower than the maximum edible sizes. For a given prey species, size selection in the field correlated closely with the size-dependent profitability relationships. Species selection had no apparent dependence upon handling-time profitability, species-dependent satiation level or gastric evacuation rate. Additional factors of probable importance include prey evasiveness, prey abundance, habitat patchiness and abiotic factors such as prevailing light conditions.
\end{abstract}

KEY WORDS: Atlantic cod · Feeding · Foraging $\cdot$ Gadus morhua $\cdot$ Prey selection $\cdot$ Satiation $\cdot$ Stomach contents

\section{INTRODUCTION}

It is common in the study of marine ecosystems to examine predator-prey relationships using predator stomach contents. However, the value of such studies may be transient in that their findings are not directly transferable to different habitat conditions, either temporally or spatially, because of fluctuations in community structure. These studies have more general merit if the mechanisms involved in prey selection can be identified, since they provide a broader, more widely applicable understanding of the predator-prey relationships involved.

\footnotetext{
-Present address: Institute of Biomedical and Life Sciences, Division of Environmental and Evolutionary Biology, Graham Kerr Building, University of Glasgow, Glasgow G12 8QQ, United Kingdom. E-mail: s.a.arnott@udcf.gla.ac.uk
}

Such studies are prevalent among predator-prey systems of high economic importance, since they form an essential component for evaluating trophic status and applying ecosystem models. For example, the literature on the diet composition of gadoid species such as cod Gadus morhua, whiting Merlangius merlangus and haddock Melanogrammus aeglefinus has been extensive over recent decades (e.g. Nagabhushanam 1965, Daan 1973, Waiwood \& Majkowski 1984, Mattson 1992, Singh-Renton \& Bromley 1999), but for the most part these studies tend to be descriptive. Details regarding the underlying mechanisms that determine diet composition are less well understood, and yet such information is vital for interpreting variable predator responses to changeable community regimes.

We have addressed this issue in 1-group cod Gadus morhua, a species that is heavily fished and of considerable economic importance, but which has come under 
considerable threat in recent years (e.g. Hutchings \& Meyers 1994, Cook et al. 1998). We examined prey selection processes in a shallow bay ( $<1 \mathrm{~m}$ depth) within the Gullmarsfjord on the Swedish west coast. In this region (Pihl 1982, Gibson et al. 1998), as in many other areas (Keats 1990, Keats \& Steele 1992, Methven \& Bajdik 1994, Gibson et al. 1995a, Gibson \& Robb 1996), juvenile cod move inshore at dusk to feed and move offshore again at dawn. Pihl (1982) reported that, during most months of the year, the main prey items (by wet wt) of 1-group cod in the Gullmarsfjord comprise the shore crab Carcinus maenas, followed by the brown shrimp Crangon crangon. Other items in the diet included polychaetes Nereis spp., Amphipoda, Gobiidae, and juvenile plaice Pleuronectes platessa.

We conducted a detailed comparison of size-specific prey availiability and selection in the field for 3 of these prey species, Carcinus maenas, Crangon crangon and Pleuronectes platessa. In addition, laboratory experiments were performed to compare the feeding responses of 1-group cod with respect to different sizes and species of these prey. The objective of the study was to provide a functional explanation for the patterns of prey selectivity observed in situ.

\section{MATERIALS AND METHODS}

Laboratory experiments. Animals: 1-group cod Gadus morhua were caught in May 1997 using fyke nets set at a depth of 5 to $10 \mathrm{~m}$ near the entrance of the Gullmarsfjord on the west coast of Sweden. They were transferred to a large indoor tank $(3 \times 1 \times 1 \mathrm{~m})$ provided with running seawater pumped from a depth of $30 \mathrm{~m}$ in the fjord ( $33 \mathrm{psu}, 13$ to $17^{\circ} \mathrm{C}$ between June and Sept). The tanks were illuminated by overhead fluorescent lights on a 17:7 h light-dark cycle. The cod were fed every 2 to $4 \mathrm{~d}$ on a mixed diet of frozen prawns (Pandalus borealis), frozen herring (Clupea harengus) and live food (Crangon crangon, Carcinus maenas and Pleuronectes platessa). They were kept for at least $3 \mathrm{wk}$ before being used in experiments.

Three prey species were used for experiments: juvenile shore crabs Carcinus maenas, brown shrimps Crangon crangon and juvenile plaice Pleuronectes platessa. These were caught locally at a depth $<1 \mathrm{~m}$ using a push net. Prey were maintained in separate 101 tanks under the same water and light conditions as the cod. Crustacean prey were only used in experiments if they had a hard exoskeleton (i.e. inter-moults).

Morphometric analysis: Length and wet weight (WW) of cod and prey specimens (blotted dry, starved for $24 \mathrm{~h}$ ) were determined to provide relationships between length and wet weight. Lengths were measured as maximum carapace width (CW) for crabs, tip of rostrum to tip of telson for shrimps (total length, TL), and tip of snout to tip of caudal fin (TL) for cod and plaice.

The ash-free dry weight (AFDW) of prey items was calculated using relationships derived by Pihl \& Rosenberg (1982) for each of the 3 prey species in Gullmarsfjord. For Crangon crangon, this required the initial conversion of $T L$ into minimum carapace length (CL), which was derived from the following relationship:

$$
C L=-1.0238+0.2505 T L\left(r^{2}=0.989\right)
$$

Prey consumption experiments: A series of experiments was conducted to determine the number of items of a given size that cod would consume for each prey species, and the handling time required to consume them. Experiments were conducted in a plastic tank $(0.65 \times 0.45 \times 0.30 \mathrm{~m})$ positioned behind a screen. A feeding tube (léngth $=1.5 \mathrm{~m}$, diameter $=5 \mathrm{~cm}$ ) was positioned at an angle, with its lower end almost touching the water surface and its elevated end protruding through a small hole in the screen. Aeration was provided before and at intervals during the experiments via an air stone that could be turned on and off from behind the screen, and water was renewed between each experiment. A video camera (Mintron MS-168P fitted with a Cosmicar/Pentax $4 \mathrm{~mm}$ TV lens) was mounted directly above the tank to enable predatorprey interactions to be video recorded (Hitachi VTL1100E recorder) for subsequent analysis. All experiments were conducted during periods when the water temperature in the laboratory was between 11 and $14^{\circ} \mathrm{C}$.

In each experiment, a single cod was placed in the tank and allowed to settle for 30 to $60 \mathrm{~min}$ with the air supply turned on. The air was then turned off and prey items were fed sequentially to the cod via the feeding tube at $3 \mathrm{~min}$ intervals (flushed in with 50 to $100 \mathrm{ml}$ seawater). If an item was not eaten within this time, the next item was added until a maximum of 3 prey were available within the tank. The experiment was terminated when no prey had been consumed within 60 min.

A total of 35 experiments were performed using separate cod of between 230 to $289 \mathrm{~mm}$ ( 91 to $184 \mathrm{~g}$ ). Cod and prey were measured to the nearest millimetre. These values were used for calculating the WW $(\operatorname{cod}$ and prey) and the AFDW (prey) from derived regression relationships. Fifteen of the experiments used crabs as the initial prey $(\mathrm{CW}=7.2$ to $26.0 \mathrm{~mm}$, $\mathrm{WW} \doteq 0.1$ to $4.3 \mathrm{~g}$ ), 10 used shrimps ( $\mathrm{TL}=21$ to $52 \mathrm{~mm}$, $W W=0.1$ to $1.8 \mathrm{~g}$ ), and the remaining 10 used plaice ( $\mathrm{TL}=44$ to $75 \mathrm{~mm}$, WW $=0.8$ to $4.5 \mathrm{~g}$ ). Each cod was initially fed just 1 prey species of a given size (within $20 \%$ WW of one another) until it became satiated. On 11 occasions, subsequent prey items of a different spe- 
cies and/or WW were then introduced to the tank to determine whether these would also be consumed. These subsequent items were offered do determine whether, in the field, a cod satiated on one prey type or size might have incentive to switch to another.

Video recordings were used to determine the handling time, which was defined as the time from capture until the time the item was judged to have been transferred to the stomach, as identified by the final characteristic swallowing action and opercular motion of the cod (Ellis \& Gibson 1997).

Field observations. Prey availability and predation by 1-group cod was examined in Gullmarsvik Bay $\left(58^{\circ} 18^{\prime} \mathrm{N}, 11^{\circ} 32^{\prime} \mathrm{E}\right)$, a north-facing microtidal $(0.1 \mathrm{~m})$ bay situated within Gullmarsfjord on the Swedish west coast. Details regarding the physical and faunal characteristics of the bay can be found in Pihl \& Rosenberg (1982, 1984) and Pihl (1982, 1985).

The results presented here are from field studies undertaken in the 1980's that examined the mobile epifauna (Pihl \& Rosenberg 1982) and predation by 1 group cod (Pihl 1982) within the bay. The orginal data from these studies have been combined and subjected to more detailed analyses here in to order to provide meaningful comparisons with our laboratory studies regarding prey selectivity by cod.

The analyses were performed on data collected during the months of June, July and September and the prey species examined included Carcinus maenas, Crangon crangon and Pleuronectes platessa. Abundance of prey in the bay (no. $\mathrm{m}^{-2}$ ) was determined using a $0.5 \mathrm{~m}^{2}$ drop trap, a device that is considered to sample in a non-size specific manner and to have retention rate close to $100 \%$ (Wennhage \& Gibson 1997). 1-group cod were caught using gill nets set at midnight at a depth of $1.5 \mathrm{~m}$ across the mouth of the bay. This method captured cod that had fed in the bay during the night and were migrating offshore with the approach of dawn.

The TL of each cod was measured to the nearest centimetre. The crabs, shrimps and plaice that were caught in the drop traps or retrieved from the cods' stomachs were measured to the nearest millimetre (for CW, CL and TL respectively). WW were calculated using regression 1 (above) and regressions 3 to 6 (see 'Results').

The size-frequency distribution of each prey species in the bay (i.e. no. $\mathrm{m}^{-2}$ of each $1 \mathrm{~mm}$ size class) was converted into prey:cod (P:C) length-ratio frequency distributions for each individual cod that was sampled during the same month (shrimp CL was initially converted into TL using regression 1). The mean abundance (no. $\mathrm{m}^{-2}$ ) of each P:C length-ratio size class was derived by summing the abundance of each size class and dividing by the number of cod sampled. Prey that were found in the stomachs of cod were expressed in terms of their $\mathrm{P}: \mathrm{C}$ length ratio.

The Strauss selectivity index (Strauss 1979) of each $P: C$ length-ratio size class was calculated on each of the 3 sampling dates. This linear index was used because it mitigates statistical and mathematical biases resulting from absolute and relative sample sizes (Strauss 1979), and was derived separately for each prey species using the relationship:

$$
L_{j}=r_{i}-p_{i}
$$

where $L_{j}$ is the selectivity index for size class $i, r_{j}$ is the proportion of size class $i$ in the cods' stomachs, and $p_{i}$ is the mean proportion of size class $i$ in the bay. Indices were also calculated to compare overall selection between prey species using $r_{j}$ as the proportion of prey species $i$ in the cods' stomachs and $p_{i}$ as the proportion of prey species $i$ in the bay. Possible values for the index range from -1 to +1 , with positive values indicating preference for prey type $i$ and negative values indicating avoidance or inaccessibility.

Statistical analyses. All statistical calculations were performed using Minitab 11 software (Minitab lnc.) and/or with reference to Zar (1996). Morphometric data were used for deriving relationships between prey length and wet weight by performing linear regressions on the $\log _{e}$ transformed data.

In the laboratory experiments, the amount of food eaten by each cod (number, WW and AFDW) was examined with respect to the mean prey size fed to each cod (expressed in terms of \% prey WW/cod WW), since both this and the available stomach volume scale approximately cubically. Data concerning the number of prey items eaten was $\log _{\mathrm{e}}$-transformed prior to regression analysis. Differences between regression slopes and elevations were tested using analysis of covariance (ANCOVA). The total meal size (initial prey species only) was expressed in terms of \% ( $\Sigma$ prey $\mathrm{WW} / \operatorname{cod} \mathrm{WW}$ ) and in terms of $\%$ ( $\Sigma$ prey AFDW/cod WW). For each prey species, the relationship between mean prey size and total meal size was examined using linear regression. Differences between the total meal sizes eaten for each of the 3 prey species were tested using 1-way ANOVA having tested for homogeneity of variance using Bartlett's test. Pairwise differences were determined using Tukey's post hoc tests.

Handling-time relationships were initially examined using a multiple regression model with $\mathrm{P}: \mathrm{C}$ length ratio, cod TL and stomach fullness as covariates and $\log _{e}$ (handling time) as the dependent. Stomach fullness was expressed as the proportion of prey WW already eaten/total meal size (WW). Covariates were progressively dropped from the model if they were found to be non-significant. With Crangon crangon, additional 0-group cod handling time data from Arnott 
(1996) was also included in the analysis $(\mathrm{N}=59$, cod TL $=61$ to $107 \mathrm{~mm}$ ). This provided a wider range of $\operatorname{cod}$ TLs, so that the effect of cod TL could be tested more rigorously.

The TL of cod analysed from Gullmasrsvik Bay from each field sampling occasion were compared using a Kruskal-Wallis test. Linear regression was used to examine the relationship between the amount of Carcinus maenas in a cod's stomach (\% crab WW/cod WW) and the amount of other prey species. Chi-squared tests were used to test for differences between the proportion of cod eating each prey type on each sampling occasion, and for testing between the size-frequency distribution of prey in Gullmarsvik Bay and the sizefrequency distribution of prey recovered from the cods' stomachs. Haber's correction for continuity was used in instances of $2 \times 2$ contingency tables.

\section{RESULTS}

\section{Morphometric analyses}

Relationships between length and WW measurements were as follows:

$$
\begin{aligned}
\text { Carcinus maenas WW } & =\left(2.64 \times 10^{-4}\right) \times \mathrm{CW}^{2.9733} \\
(\mathrm{n} & \left.=20, \mathrm{r}^{2}=0.997\right) \\
\text { Crangon crangon WW } & =\left(5.52 \times 10^{-6}\right) \times \mathrm{TL}^{3.2174} \\
(\mathrm{n} & \left.=90, \mathrm{r}^{2}=0.996\right) \\
\text { Pleuronectes platessa WW } & =\left(4.4 \times 10^{-6}\right) \times \mathrm{TL}^{3.2045} \\
(\mathrm{n} & \left.=21, \mathrm{r}^{2}=0.991\right) \\
\text { Gadus morhua WW } & =\left(4.6 \times 10^{-6}\right) \times \mathrm{TL}^{3.0869} \\
(\mathrm{n} & \left.=25, \mathrm{r}^{2}=0.92\right)
\end{aligned}
$$

with WW in $\mathrm{g}$ and TL and CW in $\mathrm{mm}$.

\section{Acceptance of initial prey items in the laboratory}

Cod consumed Carcinus maenas prey within the P:C length ratio of 0.03 to 0.09 (up to $2.3 \%$ cod's WW). The lower limit represents the smallest sizes offered in the laboratory, whereas the upper limit represents the upper limit that cod would accept. Crabs with a P:C length ratio of between 0.06 and 0.09 were frequently attacked but then often rejected (forcibly ejected from the mouth), even if the cod had an empty stomach.

Cod consumed Crangon crangon within a $\mathrm{P}: \mathrm{C}$ length ratio range of 0.08 to 0.22 (up to $1.5 \%$ cod's WW), which covered the full range of shrimps offered. Whereas smaller sizes were available to cod at the time of the field study (not tested in the laboratory), larger ones were not. The cod that was fed the shrimps with the largest P:C length ratio consumed 7 individuals and ate each within $30 \mathrm{~s}$ of it being introduced to the tank, suggesting that shrimps larger than this would have been readily accepted if available.

Cod consumed Pleuronectes platessa within the P:C length ratio of 0.17 to 0.31 , which reflected the full range of sizes available at the time of the experiments. The maximum of 0.31 was equivalent to a plaice with a WW equal to $4 \%$ that of the cod.

\section{Number of initial prey items consumed}

For each prey species, the total number of individuals consumed per cod decreased as relative prey size increased (Fig. 1A). $\log _{e}$ transformation of the data produced linear relationships (Table 1 ) that had similar slopes $\left(F_{2,29}=1.25, \mathrm{p}=0.301\right)$, but differed in their elevations $\left(F_{1,31}=74.01, \mathrm{p}<0.0001 ;\right.$ Fig. $\left.1 \mathrm{~B}\right)$. For prey of a given mean size ( $\%$ prey WW/cod WW), the total numbers consumed by cod increased in the order Carcinus maenas, Crangon crangon, Pleuronectes platessa.
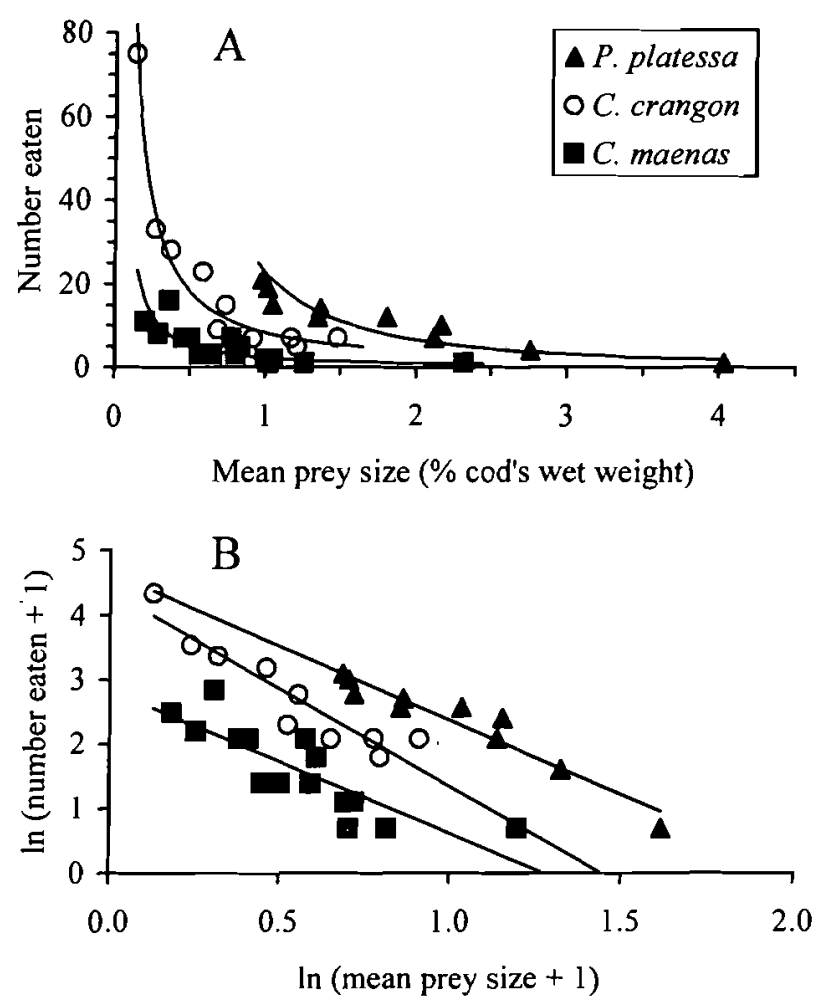

Fig. 1. Gadus morhua. (A) Relationship between mean prey size (\% prey item wet wt/cod wet wt) and number of individual prey items consumed before cod stopped feeding. (B) $\log _{\mathrm{e}}$ transformed data showing linear regression relationships, which had similar slopes but differed significantly in their elevations (see text for details). Prey species: (a) Carcinus maenas, (O) Crangon crangon, (A) Pleuronectes platessa 


\section{Total meal size (initial prey items)}

Total consumption by cod was calculated both in terms of percent (total WW eaten/cod WW) (Fig. 2A), and in terms of percent (total AFDW eaten/cod wet weight) (Fig. 2B). Within the size ranges of Carcinus maenas and Crangon crangon that were offered, prey size had no significant effect upon the total percentage of prey WW eaten ( $t$-tests on regression slopes, $t_{14}=1.03, \mathrm{p}=0.32 ; t_{9}=0.85, \mathrm{p}=0.42$ respectively) or the total percentage of prey AFDW eaten $\left(t_{14}=1.57\right.$, $\left.\mathrm{p}=0.14, t_{9}=0.92, \mathrm{p}=0.38\right)$. Mean $( \pm \mathrm{SD}) \mathrm{WW}$ consumption was $2.8 \%( \pm 1.4)$ for $C$. maenas and $9.1 \%$ $( \pm 2.4)$ for $C$. crangon, which was equivalent to mean AFDW consumption of $0.33 \%( \pm 0.18)$ and $2.13 \%$ $( \pm 0.57)$ respectively.

With Pleuronectes platessa prey, total meal size decreased significantly with individual prey size (\% WW: $t_{9}=3.61, \mathrm{p}=0.007 ; \%$ AFDW: $t_{9}=3.50, \mathrm{p}=0.008$ ), but this was mainly attributable to the single very large plaice eaten by one of the cod (see Fig. 2). For the remaining smaller plaice, there was no significant relationship $\left(t_{8}=1.28, \mathrm{p}=0.24_{i} t_{8}=1.19, \mathrm{p}=0.272\right.$ respectively), and mean consumption was $17.8 \%( \pm 3.61)$ for wet weight and $3.43 \%( \pm 0.70)$ for AFDW. The mean meal sizes of all 3 prey types (excluding the largest plaice) were significantly different from one another, both in terms wet weight (ANOVA, $F_{2,31}=107.3$, $\mathrm{p}<0.0001$; Tukey's tests, $\mathrm{p}<0.001$ for all pairwise comparisons) and $\operatorname{AFDW}\left(F_{2,31}=121.8, \mathrm{p}<0.0001 ; \mathrm{p}<\right.$ 0.001 for all pairwise comparisons).

\section{Acceptance of subsequent prey items}

Table 2 shows the acceptance by cod of subsequent prey types once they had reached satiation on the initial prey species and size offered to them. Once cod became satiated on crabs, they did not accept subse-

Table 1. Linear regression parameters describing $\ln (N+1)=$ $a \ln (S+1)+b$, where $N=$ number of prey items consumed, $S=$ mean prey size ( $\%$ prey wet $w t /$ cod wet $w t), a=$ regression slope and $b=$ regression constant. $\mathrm{n}=$ number of experiments conducted. The parameters were used for fitting the curves shown in Fig. 1

\begin{tabular}{|c|c|c|c|c|c|}
\hline & $\mathrm{n}$ & $a$ & $b$ & ANOVA & $r^{2}(\operatorname{adj})$ \\
\hline C. maenas & 15 & -2.22 & 2.84 & $\begin{array}{c}F_{1,13}=29.61 \\
\mathrm{p}<0.0001\end{array}$ & 0.67 \\
\hline C. crangon & 10 & -3.03 & 4.38 & $\begin{array}{c}F_{1,8}=55.72 \\
\mathbf{p}<0.0001\end{array}$ & 0.67 \\
\hline P. platessa & 10 & -2.29 & 4.65 & $\begin{array}{c}F_{1,8}=93.75 \\
\mathbf{p}<0.0001\end{array}$ & 0.91 \\
\hline
\end{tabular}

quent smaller crabs, but did accept plaice and shrimps, even if they were larger (WW) than crabs that the cod had already eaten. Conversely, once cod became satiated on plaice, they did not accept crabs (even very small ones), but would occasionally accept additional plaice that were smaller than those they had initially become satiated upon.

\section{Handling time}

The nature of the handling-time relationships was different with each prey species. With cod feeding on Carcinus maenas, no significant relationship was found with respect to $\mathrm{P}: \mathrm{C}$ length ratio, cod TL or stomach fullness (see Table 3 and Fig. 3). For crabs of all sizes, the median handling time was $9.0 \mathrm{~s}$ (quartiles = 5.0 and $14.0, \mathbf{n}=79$ ). With Crangon crangon, for which data from 0-group cod were also included in the analysis (from Arnott 1996), handling time increased as a positive function of both $\mathrm{P}: \mathrm{C}$ length ratio and stomach
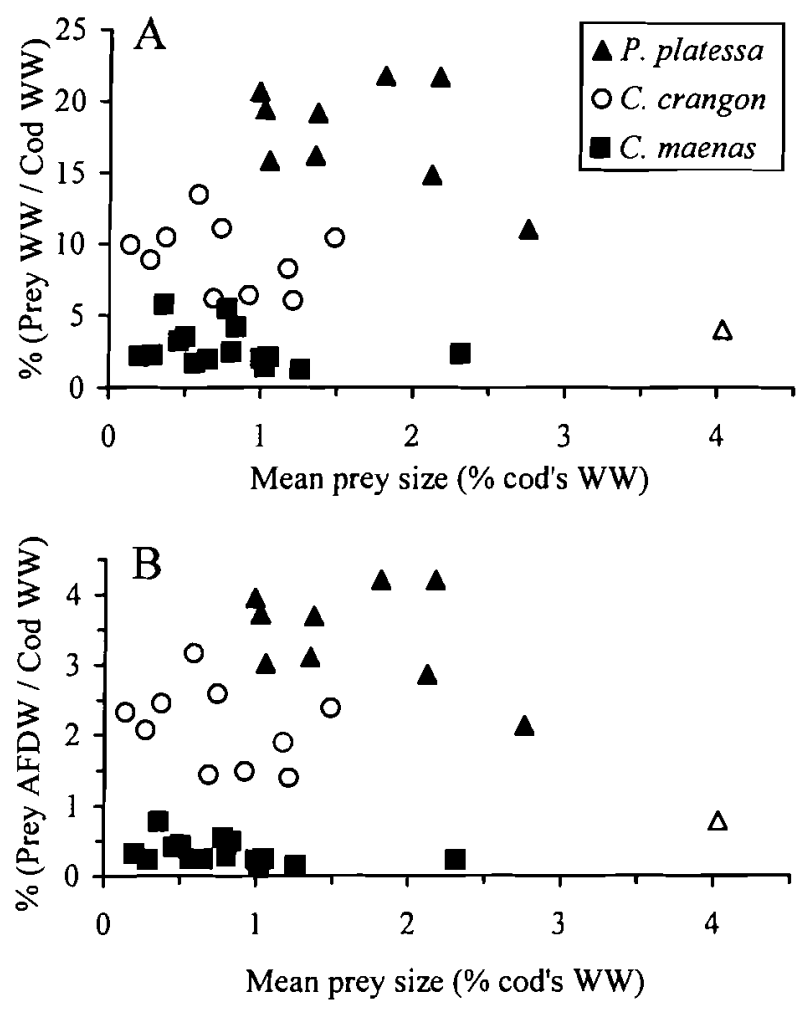

Fig. 2. Gadus morhua. Relationships between total meal size ( $\% \sum$ prey weight/cod WW) and mean prey size (\% prey item WW/cod WW) in terms of (A) total prey WW, and (B) total prey AFDW. Regression slopes for Carcinus maenas (D) and $C r a n g o n$ crangon $(O)$ were not significant. The regression slopes fitted for Pleuronectes platessa (A) were significant, but this was mainly attributable to the largest plaice $(\Delta)$ that was eaten (see text for details) 


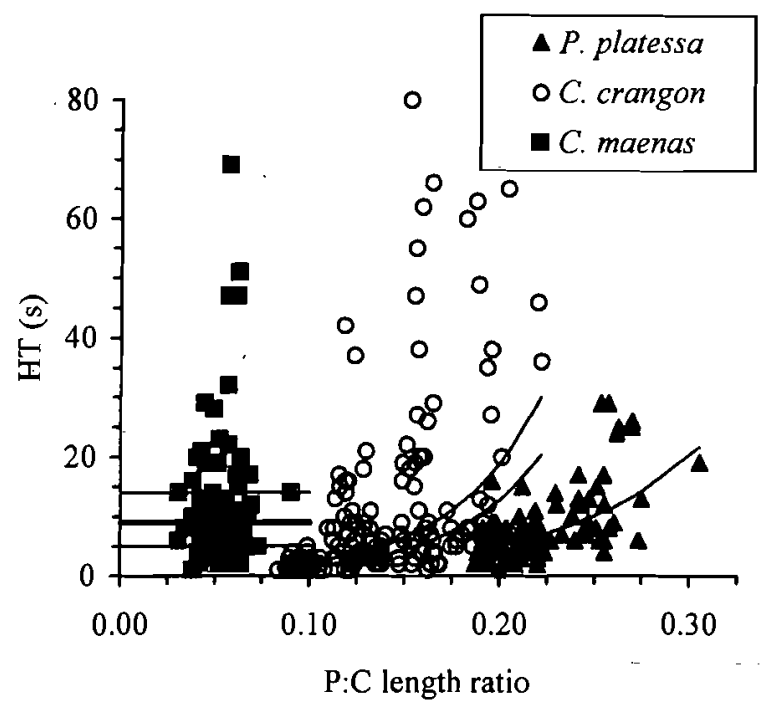

Fig. 3. Gadus morhua. Relationships between prey:cod $(\mathrm{P}: \mathrm{C})$ length ratio and handling times. The fitted lines for Carcinus maenas (ם) represent the median (thick line) and inter-quartile ranges (thin lines). The fitted lines for Crangon crangon $(O)$ and Pleuronectes platessa ( $\mathbf{\Delta}$ ) are derived from the regression equations given in Table 3 . With $C$. crangon, in which stornach fullness had a significant effect upon handling time, the lower line is fitted for cod with an empty stomach, and the upper line for cod that were half-satiated on shrimps

fullness, but there was no significant effect of cod TL. For cod feeding upon Pleuronectes platessa, handling time increased as a positive function of the P:C length ratio. There were no additional effects of cod TL or stomach fullness.

During prey handling, cod sometimes performed a vigorous head-shaking action before consuming an item. This occurred in $6.4 \%$ of encounters with Carcinus maenas ( $\mathrm{n}=79$ ), and took place within the $\mathrm{P}: \mathrm{C}$ range 0.041 to 0.064 . With Crangon crangon, head-shakes only occurred in shrimps with a P:C length ratio $>0.16$, and became increasingly common as P:C length ratio increased above this value. Handling of shrimps with an P:C length ratio $>0.18$ involved headshakes in $31 \%$ of cases $(n=19)$. With Pleuronectes platessa, headshaking activity occurred with $\mathrm{P}: \mathrm{C}$ length ratios $>0.20$, but only occurred in $4.2 \%(\mathrm{n}=95)$ of encounters within the range 0.20 to 0.31 (i.e. up to the maximum size eaten).

\section{Profitability of prey}

Estimates of handling-time profitability were derived for prey of length $i$ and species $j$ using the equation:

$$
P_{i j}=\mathrm{AFWD}_{i j} / \mathrm{HT}_{i j}
$$

where $P_{i j}$ is the profitability $\left(\mathrm{g} \mathrm{s}^{-1}\right)$ of the item, $\mathrm{AFWD}_{i j}$ is its ash-free dry weight $(\mathrm{g})$, and $\mathrm{HT}_{i j}$ is its handling time (s). The handling times of Crangon crangon and Pleuronectes platessa were estimated using the regression parameters shown in Table 3 , and error bars were fitted using handling time standard error values. With Carcinus maenas, a median handling time of $9 \mathrm{~s}$ was used for all calculations, and upper $(5 \mathrm{~s})$ and lower $(14 \mathrm{~s})$ quartiles of the handling time were used for fitting error bars.

Fig. 4 shows the handling-time profitability values of each prey species for cod of 220, 240 and $280 \mathrm{~mm}$ (the median lengths of stomach-sampled cod from Gullmarsvik Bay on each field sampling occasion see below). The profitability of Carcinus maenas, in each case, rises with crab size until the maximum size acceptable to cod is reached ( $\mathrm{P}: \mathrm{C}=0.09$ in the laboratory). With Crangon crangon and Pleuronectes plates$s a$, profitability initially increased with prey length before reaching a peak and then declining. The peak profitability of $C$. crangon occurs at a lower prey length $(\mathrm{P}: \mathrm{C} \approx 0.15)$ than with $P$. platessa $(\mathrm{P}: \mathrm{C} \approx 0.24)$, primarily because cod are able to handle large plaice more quickly than large shrimps of an equivalent length.

Table 2. Consumption of subsequent prey species and/or prey sizes once cod became satiated on initial prey items that were offered to them in the laboratory

\begin{tabular}{|c|c|c|c|c|c|c|c|}
\hline \multirow{2}{*}{$\begin{array}{l}\text { Cod } \\
\text { no. }\end{array}$} & \multicolumn{3}{|c|}{ Initial prey } & \multicolumn{4}{|c|}{ Subsequent prey } \\
\hline & $\begin{array}{c}\text { Prey } \\
\text { species }\end{array}$ & $\begin{array}{c}\text { Mean size } \\
(\% \text { WW) }\end{array}$ & $\begin{array}{l}\text { No. } \\
\text { eaten }\end{array}$ & $\begin{array}{c}\text { Prey } \\
\text { species }\end{array}$ & $\begin{array}{l}\text { Prey size } \\
(\% \text { WW })\end{array}$ & $\begin{array}{c}\text { No. } \\
\text { offered }\end{array}$ & $\begin{array}{l}\text { No. } \\
\text { eaten }\end{array}$ \\
\hline 1 & C. maenas & 0.20 & 11 & P. platessa & $0.18-0.29$ & 9 & 9 \\
\hline \multirow[t]{2}{*}{2} & C. maenas & 1.00 & 2 & C. maenas & 0.49 & 1 & 0 \\
\hline & & & & P. platessa & 0.64 & 1 & 1 \\
\hline 3 & C. maenas & 0.65 & 3 & P. platessa & 0.72 & 1 & 0 \\
\hline 4 & C. maenas & 0.36 & 16 & P. platessa & 0.77 & 1 & 0 \\
\hline \multirow[t]{3}{*}{5} & C. maenas & 0.84 & 5 & C. crangon & $1.02-1.22$ & 3 & 3 \\
\hline & & & & C. maenas & 0.79 & 1 & 0 \\
\hline & & & & C. crangon & $0.86-1.03$ & 3 & 3 \\
\hline \multirow[t]{4}{*}{6} & P. platessa & 1.37 & 14 & C. maenas & $0.20-0.84$ & 4 & 0 \\
\hline & & & & P. platessa & 0.70 & 1 & 1 \\
\hline & & & & C. maenas & $0.11-0.50$ & 3 & 0 \\
\hline & & & & $P$. platessa & 0.61 & 1 & 1 \\
\hline 7 & P. platessa & 1.02 & 19 & C. maenas & $0.17-0.81$ & 4 & 0 \\
\hline 8 & P. platessa & 1.35 & 12 & C. maenas & $0.25-1.18$ & 4 & 0 \\
\hline 9 & P. platessa & 0.98 & 21 & C. maenas & $0.55-0.88$ & 4 & 0 \\
\hline \multirow[t]{2}{*}{10} & P. platessa & 4.03 & 1 & C. maenas & 0.96 & 1 & 0 \\
\hline & & & & P. platessa & 1.08 & 1 & 0 \\
\hline 11 & P. platessa & 1.05 & 15 & C. maenas & 1.01 & 1 & 0 \\
\hline
\end{tabular}



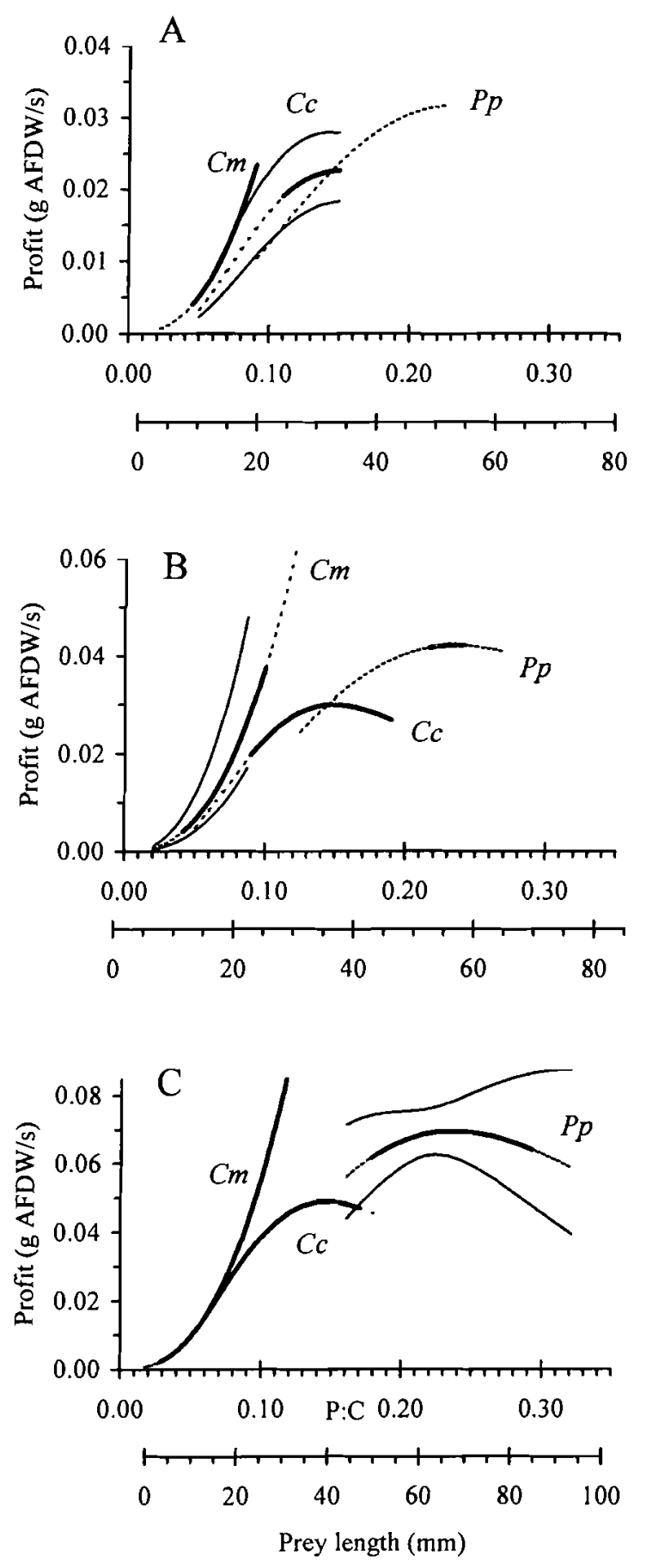

Fig. 4. Gadus morhua. Calculated handling-time profitability curves of different prey sizes and prey species during (A) June, (B) July and (C) September for median sized cod in Gullmarsvik Bay on each sampling occasion $(220,240$ and $280 \mathrm{~mm}$ respectively). The upper $x$-axis represents prey size in terms of the prey:cod (P:C) length ratio, whilst the lower $x$-axis represent absolute prey length in $\mathrm{mm}$. Cm: Carcinus maenas; $C c$ : Crangon crangon; Pp: Pleuronectes platessa; Dashed line: prey sizes present in bay but not eaten; bold solid line: prey sizes present in bay and eaten; thin solid lines: error bars derived from handling-time inter-quartile ranges $(\mathrm{Cm})$ or standard errors $(C C$ and $P p)$
Stomach fullness will affect the profitability of Crangon crangon because it has a significant effect upon handling time of shrimps (Table 3). With stomach fullness indices of 0.5 (stomach contents $\approx 4.5 \% \mathrm{WW}$ of cod) and $0.9(\approx 8.1 \%)$, respective profitability values were about 68 and $50 \%$ of values calculated for cod with empty stomachs.

\section{Field observations}

The median length of the cod from the bay whose stomachs were sampled increased from $220 \mathrm{~mm}(\mathrm{n}=36)$ in June to $240 \mathrm{~mm}(\mathrm{n}=42)$ in July and $280 \mathrm{~mm}(\mathrm{n}=52)$ in September (Kruskal-Wallis test; $H_{2}=61.08, p<0.0001$ ).

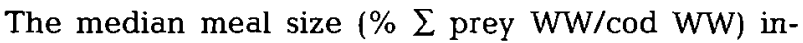
creased from $0.9 \%$ in June to $1.6 \%$ in July and $1.8 \%$ in September (Kruskal-Wallis test, $H_{2}=22.25, \mathrm{p}<0.0001$ ). In June and July, cod fed almost entirely upon Carcinus maenas, but by September Crangon crangon and, to a lesser extent, Pleuronectes platessa were also included in the diet (Fig, 5). Considering the field abundance of all 3 prey species together, crabs were strongly selected for during June and July (Strauss indices $=+0.32$ and +0.52 respectively) whereas shrimps were strongly avoided (indices $=-0.30$ and -0.52 ) and no particular preference was given to plaice (indices = -0.02 and +0.02 ). In September, the cod population as a whole showed no particular preference for any one of the prey species (indices $=+0.04,-0.09$ and +0.05 for crabs, shrimps and plaice respectively), but diet composition differed markedly between individual cod. There was a negative relationship between the amount of $C$. maenas in a cod's stomach ( $\% \sum$ crab WW/cod WW) and the amount of other prey species (Pearson correlation; $\mathrm{r}=-0.414, \mathrm{n}=52, \mathrm{p}<0.001$ ), reflecting the fact that some cod fed almost exclusively on crabs whereas others had a mixed diet or fed mainly upon C. crangon and/or P. platessa (see Fig. 5C).

Fig. 6A,D,G show (in terms of P:C length ratios) the abundance of different size-classes of crabs in the field and in cod stomachs during June, July and September, respectively. Availability of Carcinus maenas prey in Gullmarsvik Bay was confined to 1-group crabs during June and July, and the density (no. $\mathrm{m}^{-2}$ ) of this cohort declined as the season progressed. By September, newly recruited 0 -group individuals were also present. Crabs were eaten by 67 to $84 \%$ of the cod during the 3 sampling periods (no significant difference between months; chi-square test, $\chi^{2}{ }_{2}=3.37, \mathrm{p}<0.186$ ). The sizedistribution of crabs in the cods' stomachs was significantly different from that available in the bay on each occasion (chi-square tests; $\chi^{2}{ }_{7}=33.6, \mathrm{p}<0.0001 ; \chi^{2}{ }_{7}=$ 23.7, $\mathrm{p}<0.001 ; \chi^{2}{ }_{6}=70.4, \mathrm{p}<0.0001$ for June, July and September respectively). 1-group crabs had peak den- 
Table 3. Multiple regression analysis of handling time (HT) with respect to the prey:cod length ratio (P:C), cod total length (TL) and stomach fullness (SF). In the analysis, $\ln (\mathrm{HT})=a+b(\mathrm{P}: \mathrm{C})+c(\mathrm{TL})+d(\mathrm{SF})$. Analysis of Crangon crangon included additional data from Arnott (1996) for 0-group cod. ns; not significant

\begin{tabular}{|c|c|c|c|c|c|c|}
\hline Prey species & $\begin{array}{c}\text { Regression } \\
\text { constant }\end{array}$ & $\mathrm{P}: \mathrm{C}$ & TL & $\mathrm{SF}$ & $\begin{array}{c}\text { Regression } \\
\text { ANOVA }\end{array}$ & $\mathbf{r}^{2}$ (adj.) \\
\hline C. maenas & $\begin{array}{c}\text { ns } \\
t_{78}=0.27 \\
\mathrm{p}=0.789\end{array}$ & $\begin{array}{c}\mathrm{ns} \\
t_{78}=0.61 \\
\mathrm{p}=0.546\end{array}$ & $\begin{array}{c}\mathrm{ns} \\
t_{78}=1.65 \\
\mathrm{p}=0.103\end{array}$ & $\begin{array}{c}\mathrm{ns} \\
t_{78}=0.02 \\
\mathrm{p}=0.984\end{array}$ & $\begin{array}{c}\mathrm{ns} \\
F_{3,75}=1.46 \\
\mathrm{p}=0.232\end{array}$ & - \\
\hline C. crangon & $\begin{array}{c}a=-1.7304 \\
t_{234}=6.74 \\
p<0.0001\end{array}$ & $\begin{array}{c}b=+21.407 \\
t_{234}=16.53 \\
p<0.0001\end{array}$ & $\begin{array}{c}\mathrm{ns} \\
t_{234}=1.25 \\
\mathrm{p}=0.213\end{array}$ & $\begin{array}{c}d=+0.7813 \\
t_{234}=3.56 \\
p<0.0001\end{array}$ & $\begin{array}{c}F_{2,232}=151.79 \\
\mathrm{p}<0.0001\end{array}$ & 0.56 \\
\hline P. platessa & $\begin{array}{c}a=-1.1206 \\
t_{104}=2.61 \\
p<0.011\end{array}$ & $\begin{array}{c}b=+13.740 \\
t_{104}=7.05 \\
\mathrm{p}<0.0001\end{array}$ & $\begin{array}{c}\mathrm{ns} \\
t_{104}=0.73 \\
p=0.468\end{array}$ & $\begin{array}{c}\mathrm{ns} \\
t_{104}=1.52 \\
\mathrm{p}=0.131\end{array}$ & $\begin{array}{c}F_{1,103}=49.70 \\
p<0.0001\end{array}$ & 0.32 \\
\hline
\end{tabular}

sities in the bay at a P:C length ratio of 0.05 during all months, but in September the 0-group crabs created a higher peak at a P:C ratio of 0.02 . The range of $P: C$ length ratios available (and the range eaten) during June, July and September was 0.02-0.10 (0.04-0.09), $0.02-0.13(0.04-0.10)$ and $0.01-0.17(0.02-0.12)$ respectively. From the Strauss selectivity indices (Fig. 6J), it is evident that the difference between the sizes of crabs in the bay and the sizes found in the cods' stomachs arose from avoidance (or inaccessibility) of the smaller crabs in the bay and preference for the intermediate-to-large sized crabs. The only exception to this was during September when the larger of the 0group crabs $(\mathrm{P}: \mathrm{C} \approx 0.03$ ) were also included in the diet, although selection for this size class was not as strong as for the 1-group. crabs. Peaks in the selectivity indices occurred at $P: C$ length ratios of $0.07,0.09$ and 0.08 during the 3 respective sampling occasions.

Field densities of Crangon crangon were lower than Carcinus maenas in June, and very few shrimps were found in the cod stomachs. Large recruitments of shrimps were evident in both July and September, such that $C$. crangon became the most abundant of the 3 prey species in the bay. This was accompanied by an increase in predation pressure upon themi from June to September, the proportion of cod with shrimps in their diet increased from 8 to 38 and $96 \%$ respectively (significantly different between months; chi-square test, $\chi_{2}^{2}=71.47, \mathrm{p}<0.0001$ ). In June, there were too few shrimps in the cods' stomachs to compare the size distribution with that available in the bay, but in July and September significant differences were found between the distributions $\left(\chi_{4}^{2}=104.4, \mathrm{p}<0.0001, \chi_{12}^{2}=194.2\right.$, $\mathrm{p}<0.0001$, respectively). The range of $\mathrm{P}: \mathrm{C}$ length ratios available in the bay (and the range eaten) were $0.04-0.17 \quad(0.11-0.15), \quad 0.03-0.20 \quad(0.09-0.17)$ and $0.03-0.20(0.05-0.17)$ during June, July and September respectively (Fig. 6B,E,H). The selectivity indices
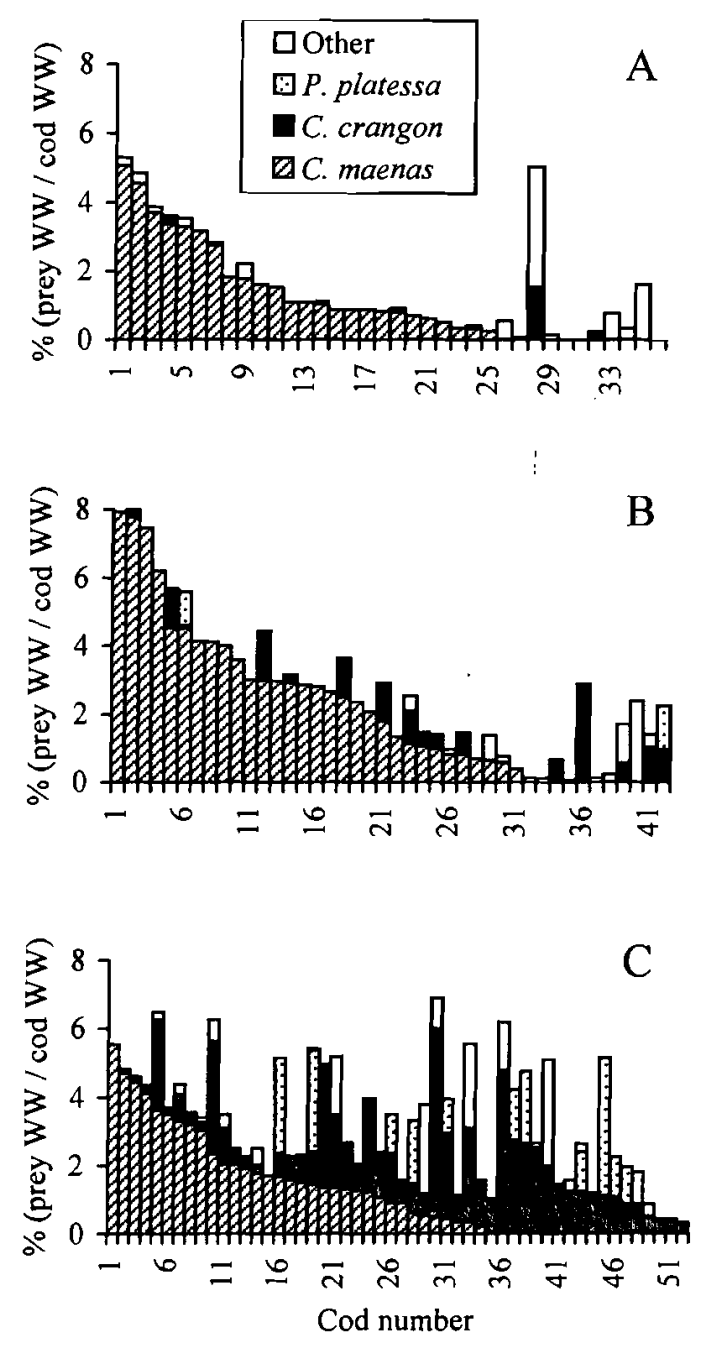

Fig. 5. Total meal size (\% $\sum$ prey WW/cod WW) of each cod caught at Gullmarsvik Bay in (A) June, (B) July and (C) September, and proportion of each meal comprising Carcinus maenas, Crangon crangon, Pleuronectes platessa and 'other' prey species 
Carcinus maenas
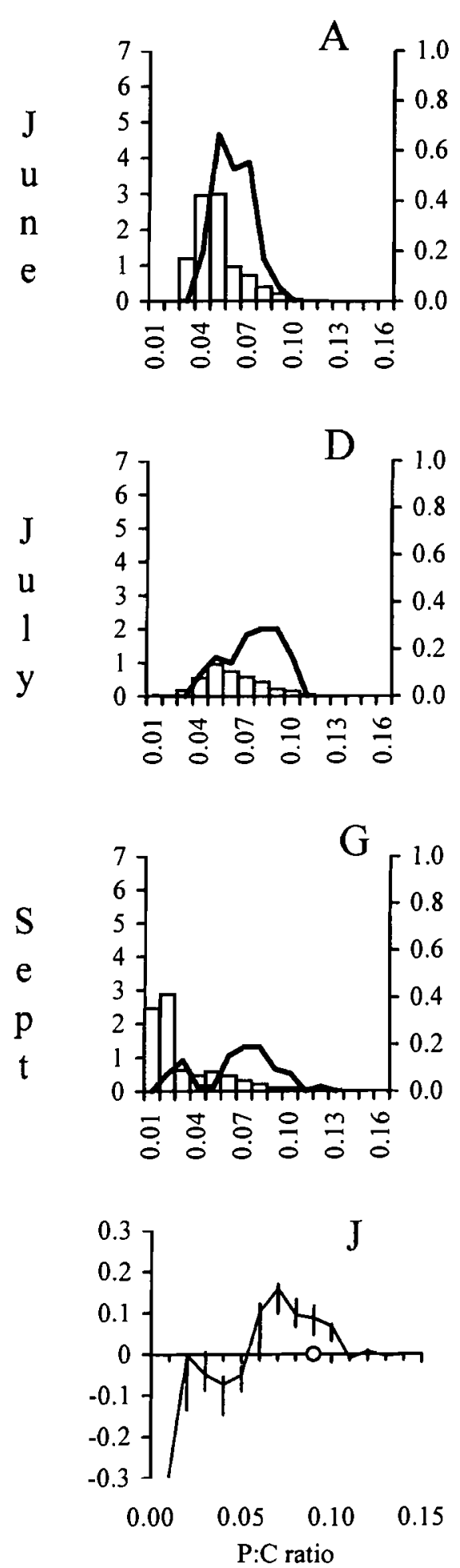

Crangon crangon
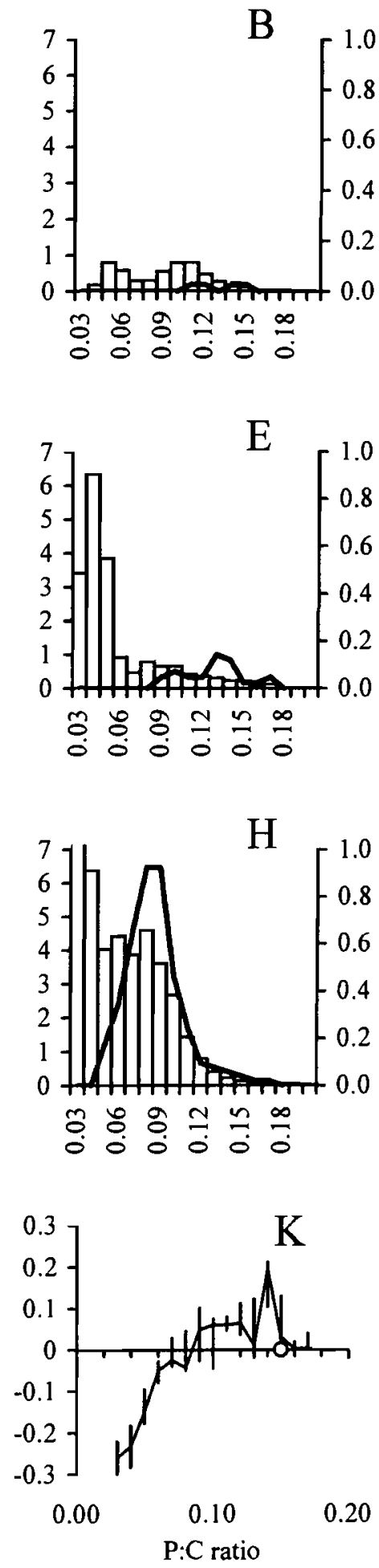

Pleuronectes platessa
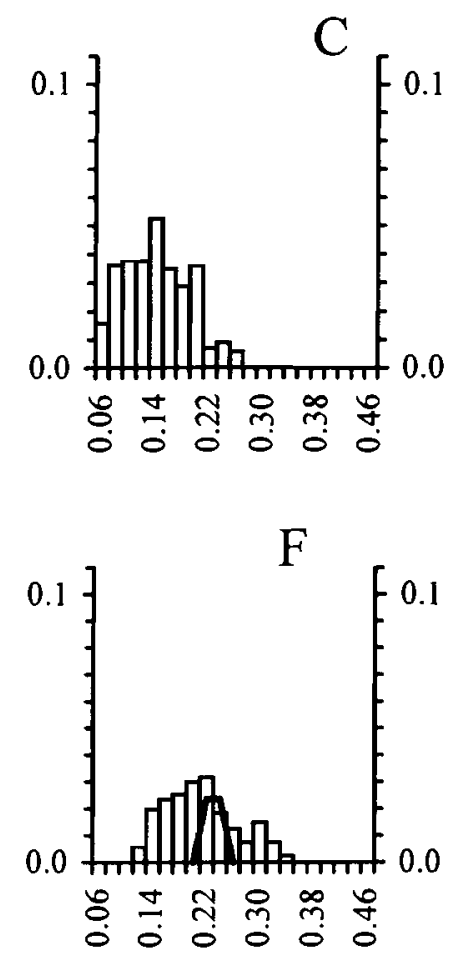

Fig. 6. Gadus morhua. Mean size-frequency distribution of Carcinus maenas, Crangon crangon and Pleuronectes platessa in Gullmarsvik Bay (bars; left axis, no. $\mathrm{m}^{-2}$ ) and in cods' stomachs (bold solid lines; right axis, no. cod ${ }^{-1}$ ) during June (A-C), July $(D-F)$ and September (G-I). (J-L) Median ( \pm inter-quartile ranges) Strauss indices of prey size classes, calculated separately for each prey species. $x$-axis represents prey size in terms of prey:cod $(P: C)$ length ratio in all cases. $(O) P: C$ length ratios with the highest profitability in the laboratory experiments 
(Fig. 6K) peaked at $\mathrm{P}: \mathrm{C}$ ratios of $0.15,0.14$ and 0.09 as the season progressed, and generally declined at lower $\mathrm{P}: \mathrm{C}$ length ratios.

Densities of 0-group plaice in the bay were approximately an order of magnitude lower than for shrimps and crabs. The proportion of cod with Pleuronectes platessa in their diet increased during the season from $0 \%$ in June to $5 \%$ in July and $21 \%$ in September (chisquare test, $\chi_{2}^{2}=12.47, \mathrm{p}<0.002$ ). Comparison between the size distributions of prey in the bay and in the cods' stomachs was only possible for the data from September, but a significant difference occurred during this month (chi-square test with Haber correction for continuity; $\chi^{2}{ }_{1}=5.49, \dot{p}<0.025$ ). The range of $P: C$ length ratios available (and the range eaten) was $0.05-0.26$ (none eaten), $0.11-0.33 \quad(0.22-0.24)$ and 0.13-0.44 (0.18-0.29) during June, Juiy and September respectively (Fig. 6C,F,I). Strauss indices were always negative at $P: C$ length ratios less than 0.16 and greater than 0.27. Between these sizes, the median index from all 3 sampling occasions peaked at a length ratio of 0.24 (Fig. 6L).

\section{DISCUSSION}

\section{Satiation levels in cod}

A predator's maximum distended stomach volume imposes an upper limit on the total amount of food that can be ingested at any one time, and stretch receptors within the stomach wall have a negative feedback effect upon appetite (Hart 1993). In addition to these influences, our laboratory experiments showed that the total wet weight of a cod's meal in the laboratory depended strongly upon the prey species being eaten (Fig. 2). Singh-Renton \& Bromley (1996) have also found meal size to be dependent upon prey type. In their studies, young cod $(25$ to $40 \mathrm{~cm}$ ) consumed greater quantities of lugworms Arenicola marina than sandeels Ammodytes spp., which themselves were eaten in greater quantities than Crangon crangon $(8.0 \%$ prey WW/cod WW compared to $9.1 \%$ in our study). Similarly, Bromley (1991) found that cod ate more sprats Sprattus sprattus than Norway Iobster Nephrops norvegicus. Since prey wet weight is closely related to prey volume (prey densities: $1.13 \mathrm{~g} \mathrm{~cm}^{-3}$ for Carcinus maenas - author's unpubl. data; $1.09 \mathrm{~g} \mathrm{~cm}^{-3}$ for Crangon crangon-Kils $1982 ; 1.08 \mathrm{~g} \mathrm{~cm}^{-3}$ for Pleuronectes platessa-Gibson et al. 1995b), these studies indicate that satiation level is not fully dependent upon just the volume of food eaten. Prey palatability may be important, but it is also likely that differences between prey shape and consistency were responsible for inter-species variability in satiation levels, since these factors will affect the packing of prey within the stomach. For instance, examination of the stomachs from plaice-satiated cod in the laboratory revealed that consumed fish become stacked flat against one another once eaten, thereby minimising the gaps between one item and the next. In contrast, prey items with a more rounded shape, such as crabs, probably pack less efficiently because they leave unfilled interstitial spaces between each item. The relatively non-pliable exoskeleton of crabs also means that they will not deform so easily to occupy these spaces as the stomach fills, particularly since no evidence was found of prey being crushed by the cod during handling. In addition, crabs possess sharp spines that may protrude into the stomach wall as the stomach becomes packed, and in both the laboratory and field studies, crabs were sometimes retrieved from cod stomachs still-alive and mobile (whereas shrimps and plaice were always dead). If crabs are able to move within the stomach for a while after being eaten, they may cause additional stimulation of the stomach's stretch receptors, thereby reducing appetite. Shrimps lie between crabs and plaice in this scheme of compactness because they can be folded within the cod's stomach (pers. obs.) and their exoskeleton is less thick and rigid than that of crabs.

In the laboratory, the maximum meal size observed for a cod that fed on crabs was $5.8 \%$ of the fish's body wet.weight. In the field, only 4 fish out of the 130 examined contained a greater wet weight percentage of crabs in their stomachs (the maximum field value was $7.9 \%$ ), and all 4 of these were caught in July. Therefore, the satiation level obtained in the laboratory appears to realistically reflect the limit that operates in situ. It is possible that those cod that ate greater quantities in the field may have eaten soft-shelled postmoult crabs that packed better within the stomach. Alternatively, higher temperatures in Gullmarsvik Bay may have led to higher satiation levels (Singh-Renton \& Bromley 1996).

When cod became satiated on crabs in the laboratory, they continued to show signs of hunger. On numerous occasions they were observed to repeatedly attack but then reject additional crabs that were offered to them, as do sticklebacks Gasterosteus aculeatus as they reach satiation on Asellus prey (Hart \& Ison 1991, Hart \& Gill 1992). Furthermore, crab-satiated cod continued to feed if they were offered shrimps or plaice (Table 2), whereas plaice-satiated cod never subsequently consumed crab prey (even if they were very small). Therefore, the species-dependent hierarchy in initial satiation remained fixed with respect to subsequent prey items that were offered. This suggests that once cod approach satiation on crabs in the field, they should switch to eating shrimps or plaice. No evidence was found for this at Gullmarsvik Bay; those cod that 
contained the greatest quantities of crabs in their stomachs tended to contain very few other types of prey (Fig. 5), possibly because they do not reach this state until the end of the nocturnal foraging period. Alternatively, there may be disadvantages to eating too much food at once in situ, since cod that were heavily satiated on plaice in the laboratory had notably rounded abdomens and showed exaggerated opercular ventilation. This may hinder swimming efficiency and escapeperformance from predators. Also, since post-prandial oxygen consumption rates of fish increase with meal size (Jobling 1993), excessive feeding bouts may potentially compromise the energetic efficiency with which prey are utilised.

\section{Potential effects of satiation levels and gastric evacuation rates}

Differences between contrasting prey types in their digestion rates and absorption efficiencies may affect the net rate of energy intake by fish. For instance, Lankford \& Targett (1997) found that weakfish Cynoscion regalis grew faster on a diet of mysids Neomysis americana than on a diet of shrimps Crangon septemspino$s a$, despite the fact that mysids were captured swallowed less efficiently. However, mysids were cleared from the fishes' guts more quickly than shrimps, increasing the overall feeding rate. Conversely, Kaiser et al. (1992) found that handling-time efficiency was a better predictor of prey choice than digestion efficiency in the fifteen-spined stickleback Spinachia spinachia.

Numerous experimental studies on cod have shown that gastric evacuation rates are faster for fish prey than for crustacean prey (e.g. Bromley 1991, SinghRenton \& Bromley 1996), and that the rates of the latter are probably dependent upon the thickness of the prey's exoskeleton. For a given prey species, gastric evacuation rate increases in proportion to meal size, whereas the size of the individual prey items that comprise the meal have little effect, at least across the range spanned by a single prey species (dos Santos \& Jobling 1991, Jobling 1996). Furthermore, in our study, individual prey size had no effect upon satiation level across the range of sizes tested, except for one particularly large plaice that was consumed (probably due to inefficient packing within the stomach; Fig. 2). Therefore, regardless of prey size, juvenile cod probably evacuate Pleuronectes platessa faster than Crangon crangon, and $C$. crangon are evacuated faster than Carcinus maenas because of their thinner exoskeleton (Jones 1974).

Factors that may be of importance in determining prey species selectivity include the effects of available foraging time, species abundance and patchiness, and species-specific satiation levels and digestion rates. In the study of Lankford \& Targett (1997), in which prey selection and growth rate were related to gastric evacuation rate rather than handling-time efficiency, prey densities were high, and field studies indicated that the weakfish foraged continuously throughout the day. By contrast, juvenile cod entering Gullmarsvik Bay apparently feed only at night, since their stomachs are empty at dusk and full at dawn (Pihl 1982), and they only have a few hours to feed during the mid-summer period when nights are short (Gibson et al. 1998). Therefore, the net rate of energy intake is unlikely to be restricted by gastric evacuation, since stomach capacity will not be a limiting factor during much of the available foraging period (assuming the stomach is not filled on immediately entering the bay). Similarly, the slower digestion rate of crabs may be compensated for by the longer daylight hours, during which cod seek refuge from predators in deeper water (Gotceitas et al. 1995, 1997, Tupper \& Boutilier 1995, Fraser et al. 1996, Borg et al. 1997), and presumably reduce or cease feeding. Crabs and shrimps were more abundant and occur in the outer and middle parts of the bay, so incoming cod will encounter these before other species, such as plaice, which move further inshore at night (Gibson et al. 1998). Furthermore, capture of crabs will be easier and less energetically expensive than with evasive prey such as shrimps and plaice.

\section{Handling times and handling profitability of prey}

Since, in the laboratory investigation, cod only consumed prey whole, the upper size limit available to them was limited by their mouth gape (Hambright 1991). Handling times of shrimps and plaice increased with relative prey size, a response typical of fish predators, whereas handling of crabs was unusual since no relative size effect was found. This may have been partly attributable to the variable response of crabs to an approaching cod; some crabs adopted and aggressive posture with their chelipeds extended (Sneddon et al. 1997) whereas others did not. In addition, the more rigid and rounded body form of Carcinus maenas may allow the prey to be transported with fewer 'gulps' into the stomach once it had been correctly aligned. Large shrimps and plaice, being more elongated, had to be fed into the stomach in stages, and are also capable of escaping from a cod's mouth after capture (Arnott 1996, Ellis \& Gibson 1997, personal observations during this study), which may prolong the time that cod take in manipulating them for consumption. As a result, the handling time profitability of crabs increased with crab size across the range of sizes eaten in the lab- 
oratory, peaking at a $\mathrm{P}: \mathrm{C}$ length ratio of 0.09 . However, cod became increasingly likely to reject crabs as they approached this upper limit, perhaps because of the protruding spines and powerful chelipeds of $C$. maenas, which may have interfered with prey handling. With shrimps, handling times were greater than those for plaice at a given P:C ratio (Fig. 3), probably because of their more cylindrical shape, more rigid exoskeleton, and greater wet weight and volume for a given total length (ca $30 \%$ greater than plaice). Consequently, the optimal handling time profitability occurred at a lower $P: C$ length ratio for shrimps $(0.15)$ than for plaice $(0.24)$, the latter of which had similar ingestion times to those of smaller 0-group cod feeding on plaice of equivalent P:C length ratios (Ellis \& Gibson 1997). The difference in handling times between shrimp and plaice prey matches the pattern found by Hoyle \& Keast (1986) for predatory largemouth bass Micropterus salmoides feeding on crayfish versus fish prey. Consumption of soft post-moult crabs and shrimps may, however, enhance their profitability, assuming they can be captured and handled more efficiently than the inter-moult stages (Stein 1977). Gordon (1974) observed higher numbers of post-moult Crangon septemspinosa than inter-moults in adult weakfish, suggesting that this strategy may be beneficial, but this aspect was not investigated during our field study.

For a particular prey species, the size-selectivity of cod in Gullmarsvik Bay related closely to the sizespecific handling-time profitability results derived from the laboratory experiments. Small, low-profit crabs (Fig. 4) had negative selection indices whereas larger high-profit crabs with $P: C$ length ratios of 0.06 to 0.10 were positively selected (Fig. 6 G). Peak selectivity for Carcinus maenas in the field occurred at $P: C$ length ratios of 0.07 to 0.09 , suggesting that cod were less likely to reject crabs of this size in situ than they were in the laboratory. This may have been because the cod in the laboratory were used to being fed on easily accessible shrimps and plaice, whereas those in Gullmarsvik Bay were used to feeding mostly on crabs. Higher temperatures in Gullmarsvik Bay may also have enhanced the cods' appetites (Singh-Renton \& Bromley 1996). With shrimps, small relatively unprofitable shrimps had negative selection indices, whereas larger more profitable $P: C$ length ratios in the $P: C$ range 0.09 to 0.15 had positive indices (Fig. $6 \mathrm{~K}$ ). In the laboratory, peak profitability occurred at a P:C length ratio of 0.15 , but the majority of shrimps available to the cod in the field were smaller than this. Cod appeared to particularly favour plaice with a P:C length ratio of around 0.24 in Gullmarsvik Bay, whilst ignoring most other sizes (Fig. 6L). Although this peak in selectivity coincides with the peak profitability in the laboratory, such apparent size specificity is surprising since the handling time profitability curve for plaice was relatively flat (Fig. 4). The negative selection indices found for smaller plaice ( $\mathrm{P}: \mathrm{C}$ range 0.14 to 0.20 ) are largely attributable to the small number of plaice eaten during June and July; the indices for these sizes during just September were in fact around zero, indicating no particular preference of avoidance. However, selectivity of plaice with length ratios $>0.27$ were consistently negative. At this length, profitability declined with size, and the experiments in the laboratory suggest that these plaice pack poorly in the stomach since satiation levels were lowered (Fig. 2). Ellis \& Gibson (1995) found that 0-group cod feeding on flatfish (Pleuronectes platessa, P. flesus and Limanda limanda) on the west coast of Scotland had a mean P:C length ratio of 0.28 in their stomachs, which may have been slightly greater than in our study because one of the prey species ( $L$. limanda) has a narrower body and is handled more easily than plaice (Ellis \& Gibson 1997), and relatively few smaller prey were available.

Whilst the handling-time profitability results derived in the laboratory correlated well with size selection in the field for each prey species, on its own handlingtime profitability was not such a good predictor of prey species selectivity. For instance, in September shrimps with a relatively high profitability were several times more abundant than crabs of equivalent or lower profitability, but many of the cod continued to consume crabs (Fig. 5C). In our experiments, ash-free dry weight has been used to give an approximation of prey energy content. We have not examined specific nutritional qualities, such as protein and lipid composition, but differences between prey composition may significantly affect their actual profitability. Another important factor not considered in our profitability calculations was the pursuit time require by cod to capture prey. As such, the profitability of evasive prey species (i.e. Crangon crangon and Pleuronectes platessa) will be overestimates, since they fail to account for the time invested in prey capture. Pursuit times of 0-group cod capturing $C$. crangon and $P$. platessa may be as long as 10 s (Arnott 1996, Ellis \& Gibson 1997). Furthermore, prey species availability was considered on the basis of their abundance in the bay, but does not account for the fact that evasive prey will not always be captured once encountered, especially in dark conditions when the ability to visually track and pursue prey may be impeded (Moore \& Moore 1976). In addition, stomach fullness had no significant effect upon the handling time of crabs, whereas shrimp handling times increased significantly as cod became satiated, reducing their profitability. This effect was not evident with plaice, although Ellis \& Gibson (1997) found that this was a significant factor in their study of 0 -group cod. 
In the field, habitat segregation and diurnal activity patterns probably also have a major influence upon prey selectivity of cod. Both plaice and shrimps have been shown to be patchily distributed in Gullmarsvik Bay during the daytime (Modin \& Pihl 1996). In another bay nearby, Gibson et al. (1998) found that at dusk plaice move quickly inshore into the shallows and remain inactive whilst the cod disperse inshore more slowly to feed. Neither Crangon crangon nor Carcinus maenas showed such strong migratory patterns in their study. The gradual inclusion of plaice in the cods' diet as the season progressed probably relates to 2 factors. First, as the plaice grew, their P:C length ratio increased (Fig. 6), with the result that they became more profitable to the cod (Fig. 4). Second, by September the nights are longer (dusk $\rightarrow$ dawn $\approx 10 \mathrm{~h}$ ) and cod may have more time to move further into the bay, leading to greater encounter rates with plaice that have retreated inshore.

During September, there was a clear distinction between those cod that fed almost exclusively on crabs, those that had mixed diets, and those that fed mainly on shrimps and/or plaice (Fig. 5C). This could be a result of prey patchiness, since cod encountering a profitable area of the bay rich in a particular prey type may benefit from remaining there to feed rather than moving and searching elsewhere (Hart 1993). In addition, or as a result of this, cod may also develop individual search images that condition them to feed on certain prey within restricted areas of the bay.

Acknowledgements. S.A.A. would particularly like to thank the technical staff, academic staff and students at Kristineberg Marine Research Station for assistance and support during this project. We are grateful for comments on the manuscript by Prof. Felicity Huntingford, Dr Iain Barber and 3 anonymous referees. S.A.A. was generously financed by a Royal Swedish Academy of Sciences/Göteborg University/ Munkedals AB Fellowship, and EU Large Scale Facility award.

\section{LITERATURE CITED}

Arnott SA (1996) The tail-flip escape response of the brown shrimp Crangon crangon L. in the context of predatorprey interactions. PhD thesis, University of Glasgow

Borg $\AA$, Pihl L, Wennhage $\mathrm{H}$ (1997) Habitat choice by juvenile cod (Gadus morhua L.) on sandy soft bottoms with different vegetation types. Helgol Meeresunters 51:197-212

Bromley PJ (1991) Gastric evacuation in cod (Gadus morhua L.). ICES Mar Sci Symp 193:93-98

Cook RM, Sinclair A, Stefansson G (1998) Potential collapse of North Sea cod stocks. Nature 385:521-522

Daan N (1973) A quantitative analysis of food intake of North Sea cod (Gadus morhua). Neth J Sea Res 6:479-517

dos Santos J, Jobling M (1991) Factors affecting gastric evacuation in cod, Gadus morhua L., fed single-meals of natural prey. J Fish Biol 38:697-713
Ellis T, Gibson RN (1995) Size-selective predation of 0-group flatfishes on a Scottish coastal nursery ground. Mar Ecol Prog Ser 127:27-37

Ellis T, Gibson RN (1997) Predation of 0-group flatfishes by 0group cod: handling times and size-selection. Mar Ecol Prog Ser 149:83-90

Fraser S, Gotceitas V, Brown JA (1996) Interactions between age-classes of Atlantic cod and their distribution among bottom substrates. Can J Fish Aquat Sci 53:305-314

Gibson RN, Robb L (1996) Piscine predation of juvenile fishes on a Scottish sandy beach. J Fish Biol 49:120-138

Gibson RN, Robb L, Burrows MT, Ansell AD (1995a) Tidal, diel and seasonal changes in the distribution of fishes on a Scottish sandy beach. Mar Ecol Prog Ser 130:1-17

Gibson RN, Yin MC, Robb L (1995b) The behavioural basis of predator-prey size relationships between shrimps (Crangon crangon) and juvenile plaice. J Mar Biol Assoc UK 75: 337-349

Gibson RN, Pihl L, Burrows MT, Modin J, Wennhage H, Nickell LA (1998) Diel movements of juvenile plaice Pleuronectes platessa in relation to predators, competitors, food availability and abiotic factors on a microtidal nursery ground. Mar Ecol Prog Ser 165:145-159

Gordon J (1974) Differential predation by fishes on the sand shrimp, Crangon septemspinosa (Say). PhD thesis, University of Delaware

Gotceitas V, Fraser S, Brown JA (1995) Habitat use by juvenile Atlantic cod (Gadus morhua) in the presence of an actively foraging and non-foraging predator. Mar Biol 123:421-430

Gotceitas V, Fraser S, Brown JA (1997) Use of eelgrass beds (Zostera marina) by juvenile Atlantic cod (Gadus morhua). Can J Fish Aquat Sci 54:1306-1319

Hambright KD (1991) Experimental analysis of prey selection by largemouth bass: role of predator mouth width and prey body depth. Trans Am Fish Soc 120:500-508

Hart PJB (1993) Teleost foraging: facts and theories. In: Pitcher TJ (ed) Behaviour of teleost fishes. Chapman and Hall, London, p 253-284

Hart PJB, Gill AB (1992) Constraints on prey size selection by the three-spined stickleback: energy requirements and the capacity and fullness of the gut. J Fish Biol 40:205-218

Hart PJB, Ison S (1991) The influence of prey size and abundance, and individual phenotype on prey choice by the three-spined stickleback, Gasterosteus aculeatus L. J Fish Biol 38:359-372

Hoyle JA, Keast A (1986) The effect of morphology and size on handling time in a piscivore, the largemouth bass (Micropterus salmoides). Can J Zool 65:1972-1977

Hutchings JA, Myers RA (1994) What can be learned from the collapse of a renewable resource - Atlantic cod, Gadus morhua, of Newfoundland and Labrador? Can J Fish Aquat Sci 51:2126-2146

Jobling $M$ (1993) Bioenergetics: feed intake and energy partitioning. In: Rankin JC, Jensen FB (eds) Fish ecophysiology. Chapman and Hall, London, p 1-44

Jobling M (1996) Environmental biology of fishes. Chapman and Hall, London

Jones R (1974) The rate of elimination of food from the stomachs of haddock Melanogrammus aeglefinus, cod Gadus morhua and whiting Merlangius merlangus. J Cons Int Explor Mer 5:225-243

Kaiser MJ, Westhead AP, Hughes RN, Gibson RN (1992) Are digestive characteristics important contributors to the profitability of prey? Oecologia 90:61-69

Keats DW (1990) A nocturnal inshore movement of juvenile cod Gadus morhua L. in eastern Newfoundland. J Exp Mar Biol Ecol 139:167-173 
Keats DW, Steele DH (1992) Diurnal feeding of juvenile cod (Gadus morhua) which migrate into shallow water at night in eastern Newfoundland. J Northwest Atl Fish Sci 13:7-14

Kils U (1982) The swimming behaviour, swimming performance and energy balance of the Antarctic krill, Euphausia superba. Biomass Sci Ser 3:1-121

Lankford TE, Targett TE (1997) Selective predation by juvenile weakfish: post-consumptive constraints on energy maximisation and growth. Ecology 78:1049-1061

Mattson S (1992) Food and feeding habits of fish species over a soft sublittoral bottom in the Northeast Atlantic, 3: Haddock (Melanogrammus aeglefinus, L.) (Gadidae). Sarsia 77:33-45

Methven DA, Bajdik C (1994) Temporal variation in size and abundance of juvenile cod (Gadus morhua) at an inshore site off eastern Newfoundland. Can J Fish Aquat Sci 51: 78-90

Modin J, Pihl L (1996) Small-scale distribution of juvenile plaice and flounder in relation to predatory shrimp in a shallow Swedish bay. J Fish Biol 49:1070-1085

Moore JW, Moore IA (1976) The basis of food selection in flounders, Platichthys flesus (L.), in the Severn Estuary. J Fish Biol 9:139-156

Nagabhushanam AK (1965) On the biology of the commoner gadoids in Manx waters. J Mar Biol Assoc UK 45:615-657

Pihl L (1982) Food intake of young cod and flounder in a shallow bay on the Swedish west coast. Neth J Sea Res 15: 419-432

Pihl L (1985) Food selection and consumption of mobile epibenthic fauna in shallow marine areas. Mar Ecol Prog Ser 22:169-179

Pihl L, Rosenberg R (1982) Production, abundance, and bio-

Editorial responsibility: Otto Kinne (Editor), Oldendorf/Luhe, Germany mass of mobile epibenthic marine fauna in shallow waters, western Sweden. J Exp Mar Biol Ecol 57:273-301

Pihl L, Rosenberg R (1984) Food selection and consumption of the shrimp Crangon crangon in some shallow marine areas in western Sweden. Mar Ecol Prog Ser 15:159-168

Singh-Renton S, Bromley PJ (1996) Effects of temperature, prey type and prey size on gastric evacuation in small cod and whiting. J Fish Biol 49:702-713

Singh-Renton S, Bromley PJ (1999) Feeding of small whiting (Merlangius merlangus) in the central and southern North Sea. J Mar Biol Assoc UK 79:957-960

Sneddon LU, Huntingford FA, Taylor AC (1997) The influence of resource value on the agonistic behaviour of the shore crab, Carcinus maenas (L.). Mar Freshw Behav Physiol 30:225-237

Stein RA (1977) Selective predation, optimal foraging, and the predator-prey interactions between fish and crayfish Ecology 58:1237-1253

Strauss RE (1979) Reliability estimates for lvlev's electivity . index, the foraging ratio, and a proposed linear index of food selection. Trans Am Fish Soc 108:344-352

Tupper M, Boutilier RG (1995) Effects of habitat on settlement, growth, and postsettlement survival of Atlantic cod (Gadus morhua). Can J Fish Aquat Sci 52:1834-1841

Waiwood K, Majkowski J (1984) Food consumption and diet composition of cod, Gadus morhua, inhabiting the southwestern Gulf of St Lawrence. Environ Biol Fish 11:63-78

Wennhage H, Gibson RN (1997) The use of drop traps to estimate the efficiency of two beam trawls commonly used for sampling juvenile flatfishes. J Fish Biol 51:441-445

Zar JH (1996) Biostatistical analysis. Prentice-Hall International Inc, Englewood Cliffs, NJ

Submitted: July 21, 1999; Accepted: November 16, 1999 Proofs received from author(s): May 11, 2000 